\title{
A Large Contribution of Anthropogenic Organo-Nitrates to Secondary Organic Aerosol in the Alberta Oil Sands
}

Alex K. Y. Lee ${ }^{1,2}$, Max G. Adam², John Liggio ${ }^{3}$, Shao-Meng Li ${ }^{3}$, Kun Li ${ }^{3}$, Megan D. Willis ${ }^{4}$, Jonathan

P. D. Abbatt ${ }^{4}$, Travis W. Tokarek ${ }^{5}$, Charles. A. Odame-Ankrah ${ }^{5}$, Hans D. Osthoff $^{5}$, Kevin Strawbridge $^{3}$, Jeffery R. Brook ${ }^{3}$

${ }^{1}$ Department of Civil and Environmental Engineering, National University of Singapore, Singapore

${ }^{2}$ NUS Environmental Research Institute, National University of Singapore, Singapore

${ }^{3}$ Air Quality Process Research Section, Environment and Climate Change Canada, Toronto, ON, Canada

${ }^{4}$ Department of Chemistry, University of Toronto, Toronto, ON, Canada

${ }^{5}$ Department of Department of Chemistry, University of Calgary, Calgary, AB, Canada

\# Now at Lawrence Berkeley National Lab, Chemical Sciences Division, Berkeley, CA, USA

Correspondence to: Alex K. Y. Lee (ceelkya@ nus.edu.sg)

\section{Supplementary Information}




\section{Ground-based measurements}

\subsection{Sampling location and instruments}

From August 11, 2013 to September 10, 2013, a comprehensive campaign was carried out to study air quality in northern Alberta as part of the Joint Oil Sands Monitoring (JOSM) plan. The measurements presented in this study were made at the Air Monitoring Station 13 (AMS13) ground site managed by the Wood Buffalo Environmental Association near to Fort MacKay (57.1492 ${ }^{\circ}$ N, $111.6422^{\circ}$ W, 270 asl) which is located in the scarcely populated Athabasca Oil Sands Region (Figure S1). The major developments in recent years of oil sands production and processing facilities have led to the release of air pollutants in the area (Englander et al., 2013;Li et al., 2017;Liggio et al., 2016).

A soot-particle aerosol mass spectrometer (SP-AMS) was deployed to measure chemical compositions and size distributions of aerosol particles (see later sections for detail). Details of other co-located instruments have been reported in Tokarek et al. (2018). The AMS13 site provides a comprehensive suite of meteorological and gas-phase measurements of which wind direction, wind speed, temperature, ozone $\left(\mathrm{O}_{3}\right)$, sulfur dioxide $\left(\mathrm{SO}_{2}\right)$, and nitrogen dioxides $(\mathrm{NOx})$ were used in the data analysis. Mixing ratios of nitrogen oxides $\left(\mathrm{NO}_{\mathrm{x}}=\mathrm{NO}+\mathrm{NO}_{2}\right)$ were quantified by cavity ring down spectroscopy (CRDS) (Fuchs et al., 2009;Paul and Osthoff, 2010) and total odd nitrogen ( $\mathrm{NO}_{\mathrm{y}}$ ) was measured using a Thermo Scientific $42 \mathrm{i}$ gas analyser. The data was used to elucidate the $-\log \left(\mathrm{NO}_{\mathrm{x}} / \mathrm{NO}_{\mathrm{y}}\right)$ ratio for determining the relative age of air masses (Irei et al., 2016;Takegawa et al., 2004). The mixing height data was obtained from a dual wavelength backscatter lidar operating in the zenith which is in continuous and autonomous operation except during periods of precipitation (Strawbridge, 2013).

\subsection{Soot particle aerosol mass spectrometer (SP-AMS)}

The working principle of the SP-AMS has been reported in detail previously (Onasch et al., 2012). In brief, the SP-AMS is a standard Aerodyne high-resolution time-of-flight aerosol mass spectrometer (HRToF-AMS) (DeCarlo et al., 2006) coupled with a diode-pumped Nd:YAG intracavity $1064 \mathrm{~nm}$ infrared (IR) laser vaporizer similar to that of the single particle soot photometer (SP2, Droplet Measurement Technologies). While the resistively heated tungsten vaporizer is operated at $\sim 600^{\circ} \mathrm{C}$ to vaporize nonrefractory particulate matter (NR-PM, i.e. sulfate, nitrate, ammonium, chloride and organic) (Canagaratna 
et al., 2007), the laser vaporizer expands the utility of HR-ToF-AMS to vaporize IR absorbing aerosol particles. In particular, BC particles are heated to $4000 \mathrm{~K}$ and vaporized by absorbing IR energy. Note that BC particles detected by SP-AMS are operationally defined as refractory black carbon (rBC).

An aerodynamically focused particle beam overlaps perpendicularly with the laser vaporizer before it hits the tungsten vaporizer, and hence any NR-PM that is internally mixed with rBC evaporate along with rBC. The resulting gas-phase species are ionized by electron impact approach (EI, $70 \mathrm{eV}$ ). In this study, the ions were subsequently detected by a high-resolution time-of-flight mass spectrometer operated in Vmode, which provides a mass resolving power of $\sim 2000$ at m/z 28. A single slit chopper (i.e., $\sim 2 \%$ aerosol throughput) was used for particle time-of-flight (pToF) size distribution measurements. The SP-AMS was operated alternating between IR laser-on and laser-off modes with the time resolution of one minute (i.e., 1-min average of bulk mass spectrum and PToF size distribution for both laser-on and off modes). Quantifications of NR-PM and rBC were based on laser-off and laser-on measurements, respectively, as described in the next section.

\subsection{Calibration of SP-AMS and quantification of rBC and NR-PM}

Ammonium nitrate $\left(\mathrm{NH}_{4} \mathrm{NO}_{3}\right)$ particles generated by a constant output atomizer (TSI Inc., Model 3076) were dried using a diffusion dryer, and were subsequently size selected at $300 \mathrm{~nm}$ using a differential mobility analyzer (DMA, TSI Inc., Model 3081) for determining the mass-based ionization efficiency of nitrate $\left(\mathrm{mIE}_{\mathrm{NO}}\right)$ and the ionization efficiency of ammonium relative to nitrate $\left(\mathrm{RIE}_{\mathrm{NH} 4}=\mathrm{mIE} \mathrm{NH}_{4} / \mathrm{mIE}_{\mathrm{NO}}\right)$ when the instrument was operated in the laser-off mode. Similarly, a water suspension of Regal Black (Regal 400R Pigment Black, Cabot Corp., a calibration standard recommended by Onasch et al. (2012) was atomized to generate standard rBC particles. Dried $300 \mathrm{~nm}$ Regal Black particles were used to determine the mass-based ionization efficiency of $\mathrm{rBC}\left(\mathrm{mIE}_{\mathrm{rBC}}\right)$ and the ionization efficiency relative to nitrate $\left(\mathrm{RIE}_{\mathrm{rBC}}=\mathrm{mIE} \mathrm{E}_{\mathrm{rBC}} / \mathrm{mIE}_{\mathrm{NO} 3}\right)($ Onasch et al., 2012). The mass of individual dried $300 \mathrm{~nm}$ Regal Black particles was $\sim 11.2 \mathrm{fg}$ based on aerosol particle mass analyzer measurements (APM model 3600, Kanomax Inc.) (Willis et al., 2014).

The calibration and field data were processed using the IGOR-based AMS data analysis software (Squirrel, version 1.16I for unit mass resolution (UMR) data and Pika, version 1.57I for high resolution peak fitting, http://cires.colorado.edu/jimenez-group/ToFAMSResources/ToFSoftware/ index.html) with 
the corrected air fragment column of the standard fragmentation table (Allan et al., 2004;DeCarlo et al., 2006). Signals for $r B C$ were quantified by the sum of carbon ion clusters $\left(\mathrm{C}_{\mathrm{x}}{ }^{+}\right.$, i.e. $\left.\mathrm{C}_{1}{ }^{+}-\mathrm{C}_{9}{ }^{+}\right)$using high resolution mass spectral data measured by the laser-on mode. The average $\mathrm{C}_{1}{ }^{+}$to $\mathrm{C}_{3}{ }^{+}$ratio (0.65) obtained from Regal Black was used to correct the interference in $\mathrm{C}_{1}{ }^{+}$from the non-refractory organics in ambient aerosol. The $3 \sigma$ detection limit for $\mathrm{rBC}$ mass concentration measurements is $0.01 \mu \mathrm{g} \mathrm{m}^{-3}$ for $1 \mathrm{~min}$ collection. The size distribution of $\mathrm{rBC}$ was determined by estimating $\mathrm{C}_{1}{ }^{+}$to $\mathrm{C}_{5}{ }^{+}$ion signals in Squirrel. The campaign averages of $\mathrm{RIE}_{\mathrm{rBC}}$ and $\mathrm{RIE}_{\mathrm{NH} 4}$ were 0.4 and 4.66, respectively. The default RIE values of nitrate (1.1), sulfate (1.2) and organics (1.4) were used (Jimenez et al., 2003). Collection efficiency (CE) of 0.6 was used for rBC quantification (Willis et al., 2014). NR-PM components were quantified based on the laser-off mode measurements and their CE were determined using the composition-dependent approach (Middlebrook et al., 2012).

\subsection{Positive matrix factorization of SP-AMS measurements}

Positive matrix factorization (PMF) of organic fragments determined from the laser-off, high-resolution mass spectral data was performed to identify potential sources of organic aerosol (OA). In this study, the PMF evaluation tool (PET, v2.08D) as described in Ulbrich et al. (2009) was used. The ions which have a signal-to-noise ratio (SNR) of 0.2-2.0 were downweighted by a factor of 2 , bad ions $(\mathrm{SNR}<0.2)$ were removed from the analysis and $\mathrm{CO}_{2}{ }^{+}$related ions (i.e., $\mathrm{O}^{+}, \mathrm{HO}^{+}, \mathrm{H}_{2} \mathrm{O}^{+}, \mathrm{CO}^{+}$) were downweighted. PMF results were evaluated up to 8 factors with "fpeak" varying from -1 to 1 increasing in step size 0.2 based on the procedures and criteria described by Ulbrich et al. (2009) and Zhang et al. Zhang et al. (2011). Three distinct types of OA, hydrocarbon-like OA (HOA), less-oxidized oxygenated OA (LO-OOA) and more-oxidized oxygenated OA (MO-OOA), were identified for the whole measurement period. Time series and mass spectra of the three PMF factors are presented in Figure S2 and S3 (See also Figure 1 in the main text), respectively.

Note that large variations of different aerosol species within the period of 22 August - 29 August 2013 were observed due to strong influences of emissions from oil sands operations as discussed in the main text and reported in Figure 1. PMF was also performed for this short period in order to further separate OA components that might be associated with specific oil sands emissions. In particular, this resulted in splitting of the LO-OOA factor into two OOA factors, namely sulfate-OOA and nitrate-OOA, whereas 
the temporal variations and mass concentrations of HOA and MO-OOA factors are similar to those obtained from the 3-factor solutions (Figure S2, Table S1). Sulfate-OOA and nitrate-OOA were correlated to the AMS-measured sulfate $\left(r^{2}=0.60\right)$ and nitrate $\left(r^{2}=0.81\right)$, respectively (Table S2). Elemental ratios $(\mathrm{O}: \mathrm{C} ; \mathrm{H}: \mathrm{C} ; \mathrm{N}: \mathrm{C})$ of total OA and PMF factors were determined from the method described by Canagaratna et al. (2015), and the results are presented in the Van-Krevelen diagrams (Figure S4).

\subsection{Types of OA identified by PMR analysis of organic fragments}

Three types of OA, referred to as hydrocarbon-like OA (HOA), less-oxidized oxygenated OA (LO-OOA) and more-oxidized OOA (MO-OOA) were identified based on positive matrix factorization (PMF) of organic fragments HOA accounted for $\sim 10 \%$ of total OA and was strongly correlated to two combustion tracers, $\mathrm{rBC}$ and $\mathrm{NO}_{\mathrm{x}}\left(\mathrm{r}^{2}=0.70\right.$ and 0.73 , Figure $\left.1 \mathrm{c}\right)$, primarily emitted from combustion sources such as the mining fleets during the daytime (Tokarek et al., 2018). The LO-OOA and MO-OOA factors were secondary in nature and accounted for 39 and $51 \%$ of total OA, respectively. The detail description of LOOOA factor can be referred to the main text.

Both temporal and diurnal variations of MO-OOA were modest with a minor enhancement in the afternoon (Figure 1d and 11) probably due to the combined effects of local photochemistry and atmospheric dilution. No noticeable association between MO-OOA and local wind directions was observed (Figure 1j). Therefore, MO-OOA likely represented SOA produced through photooxidation of VOCs that were relatively well-mixed in the atmosphere rather than those freshly emitted from the oil sands facilities. Liggio et al. (2016) also identified this type of background OOA, dominating outside the plumes emitted from oil sands operations in the aircraft measurements. Note that the Alberta oil sands region is largely covered by forest with significant influence of anthropogenic emissions. Both biogenic and anthropogenic precursors could contribute to the observed MO-OOA but their relative contributions require additional information to be further separated.

\subsection{Estimation of nitrate-OOA for the entire sampling period}

As illustrated in Figure S2, the LO-OOA factor split into sulfate-OOA and nitrate-OOA within the period of August 22 - August 29, 2013. Note that a huge sulfate plume observed in 23 August is more acidic 
compared to the rest of period (Figure S6). By excluding this sulfate plume, a stronger correlation between sulfate-OOA and sulfate is observed $\left(r^{2}=0.81\right)$ and the average sulfate-OOA-to-SO $\mathrm{SO}_{4}$ ratio of 0.33 was determined (Figure S5). The ratio was used to estimate sulfate-OOA and nitrate-OOA mass concentrations for the entire sampling period (Figure S7) as shown below:

$$
\begin{gathered}
{[\text { Sulfate-OOA }]=0.33 \times\left[\mathrm{SO}_{4}\right]} \\
{[\text { Nitrate-OOA }]=[\mathrm{LO}-\mathrm{OOA}]-[\text { sulfate-OOA }]}
\end{gathered}
$$

where $[\mathrm{LO}-\mathrm{OOA}]=$ Mass concentrations of LO-OOA determined from the 3 -factor solution

\subsection{Quantification of organo-nitrates (ON)}

Similar to standard AMS, SP-AMS can detect both inorganic nitrate and organo-nitrate (ON). Electron impact ionization of nitrate functional groups $\left(-\mathrm{ONO}_{2}\right)$ in organo-nitrate $(\mathrm{ON})$ generates $\mathrm{NO}^{+}$and $\mathrm{NO}_{2}{ }^{+}$ fragments. Figure $\mathrm{S} 8$ shows that the $\mathrm{NO}^{+} / \mathrm{NO}_{2}{ }^{+}$ratios of our ambient measurements are much higher than that of pure ammonium nitrate (i.e., a chemical standard for SP-AMS calibration). Our observation indicates significant contributions of $\mathrm{ON}$ to the observed $\mathrm{NO}^{+}$and $\mathrm{NO}_{2}{ }^{+}$signals (Farmer et al., 2010). Therefore, we estimated the mass concentrations of organo-nitrate based upon the ratio of the nitrate fragments $\left(\mathrm{NO}^{+} / \mathrm{NO}_{2}{ }^{+}\right)$from the SP-AMS calibration and ambient measurements as described in Farmer et al. (2010) and Xu et al. (2015). The nitrate equivalent mass concentrations of $\mathrm{NO}^{+}$and $\mathrm{NO}_{2}{ }^{+}$were averaged to $5 \mathrm{~min}$ and then substituted into the following equations:

$$
\begin{array}{r}
{\left[\mathrm{NO}_{2, \mathrm{ON}}^{+}\right]=\frac{\left[\mathrm{NO}_{2, \text { Observe }}^{+}\right] \times\left(\mathrm{R}_{\mathrm{meas}}-\mathrm{R}_{\mathrm{AN}}\right)}{\mathrm{R}_{\mathrm{ON}}-\mathrm{R}_{\mathrm{AN}}}} \\
{\left[\mathrm{NO}_{2, \mathrm{ON}}^{+}\right]=\mathrm{R}_{\mathrm{ON}} \times\left[\mathrm{NO}_{\mathrm{ON}}^{+}\right]} \\
{[\mathrm{ON}]=\left(\left(\left[\mathrm{NO}_{\mathrm{ON}}^{+}\right]+\left[\mathrm{NO}_{2, \mathrm{ON}}^{+}\right]\right) / 62\right) \times \mathrm{MW}_{\mathrm{ON}}}
\end{array}
$$


where

$$
\begin{aligned}
& \mathrm{MWON}=\text { molecular weight of organo-nitrates, }(\text { assumed }=200-300 \mathrm{~g} / \mathrm{mol}) \\
& \mathrm{R}_{\text {meas }}=\mathrm{NO}^{+} / \mathrm{NO}_{2}{ }^{+} \text {for ambient measurement data } \\
& \mathrm{R}_{\mathrm{AN}}=\mathrm{NO}^{+} / \mathrm{NO}_{2}{ }^{+} \text {for ammonium nitrate }(=3.36 \text { from on-site calibration }) \\
& \left.\mathrm{R}_{\mathrm{ON}}=\mathrm{NO}^{+} / \mathrm{NO}_{2}{ }^{+} \text {for organo-nitrate (assumed }=5-10\right)
\end{aligned}
$$

The percentage contributions of ON to nitrate-OOA mass concentrations were estimated from regression analysis as demonstrated in Figure S9. The estimations with different values of RON and MWON were summarized in Table S3.

\subsection{Single particle characterization using SP-AMS equipped with light scattering module}

Another co-located SP-AMS equipped with a light scattering module (LS-SP-AMS) was deployed in this field campaign to assess the mixing state of NR-PM components from Aug 22-29, 2013. The design and working principles of the LS module have been previously described in detail (Cross et al., 2009;Freutel et al., 2013;Lee et al., 2015; Liu et al., 2013). In brief, the LS module consists of a 405 nm continuous wave laser that overlaps perpendicularly and completely with the particle beam $\sim 0.265$ m downstream of the chopper. Scattered light from sampled particles is collected using an ellipsoidal mirror and detected with a photo-multiplier tube. An LS signal can be obtained if a sampled particle is larger than the optical detection limit. The $50 \%$ cut-off mobility diameter of the LS module determined using dried ammonium nitrate particles is $\sim 250 \mathrm{~nm}$. Once a light scattering signal is detected, the computer is triggered to save the whole pToF trace, from which the single-particle mass spectrum is subsequently obtained. The single particle categorization procedure and k-means clustering algorithm that were used to analyze the single particle data followed the description in Lee et al. (2015). Figure S10 shows the time series and mass spectrum of the sulfate-rich particle type identified in this study. This observation provides direct evidence that sulfate and organics are internally mixed in the sulfate plumes emitted from oil sands operations.

\subsection{Generation of bivariate polar plots}

A bivariate polar plot illustrates the variation of the concentration of a species with wind direction and wind speed on polar coordinates. The 5-min averaged concentrations of gas- and particle-phase species were used to generate the bivariate polar plots presented in Figure S11 and S12 using the openair package 
(www.openair-project.org) (Carslaw and Beevers, 2013). Wind speed and wind direction were binned into intervals of 5 degrees and 30 wind speed intervals, respectively, and a Generalized Additive Model (GAM) smooth was applied to the binned means. The GAM is represented in the following way:

$$
\sqrt{C_{i}}=\beta_{0}+s\left(u_{i}, v_{i}\right)+\varepsilon_{i}
$$

where

$\mathrm{C}_{\mathrm{i}}=$ ith species concentration,

$\beta_{0}=$ overall mean of the response,

$\mathrm{s}\left(\mathrm{ui}_{\mathrm{i}} \mathrm{v}_{\mathrm{i}}\right)=$ isotropic smooth function of the ith value of the covariate $\mathrm{u}$ and $\mathrm{v}$

$\varepsilon_{\mathrm{i}}=i$ th residual.

The wind components, $\mathrm{u}$ and $\mathrm{v}$ are calculated according to the following equations

$$
u=\overline{\mathrm{u}} \cdot \sin \left(\frac{2 \pi}{\theta}\right), v=\overline{\mathrm{u}} \cdot \cos \left(\frac{2 \pi}{\theta}\right)
$$

where $\quad \overline{\mathrm{u}}=$ mean hourly wind speed,

$\theta=$ mean wind direction in degrees with $90^{\circ}$ as being from the east.

\section{Laboratory flow tube experiments:}

\subsection{Estimation of $\mathrm{OH}$ exposure in the flow tube}

The $\mathrm{OH}$ exposure was estimated via the decay of methanol:

$$
[\mathrm{OH}] \mathrm{t}=-\frac{1}{\mathrm{k}_{2, \mathrm{MeOH}}} \ln \frac{[\mathrm{MeOH}]}{[\mathrm{MeOH}]_{0}}
$$

where $\mathrm{k}_{2, \mathrm{MeOH}}$ is the second order rate constant of methanol with $\mathrm{OH}$ at $298 \mathrm{~K}\left(9.4 \times 10^{-13} \mathrm{~cm}^{3}\right.$ molecule${ }^{1} \mathrm{~s}^{-1}$ (Atkinson and Arey, 2003)). The $\mathrm{OH}$ concentration was adjusted by changing the intensity of the 254 $\mathrm{nm}$ UV lamp. The $\mathrm{OH}$ exposure ranged from $1.11 \times 10^{11}$ to $3.06 \times 10^{11}$ molecule $\mathrm{cm}^{-3} \mathrm{~s}$, which corresponds 
to 4.3 - 12.2 hours when assuming a daytime $\mathrm{OH}$ concentration of $7 \times 10^{6}$ molecule $\mathrm{cm}^{-3}$ as estimated for polluted areas (Hofzumahaus et al., 2009;Stone et al., 2012) and consistent with estimations for oil sands plumes (Liggio et al., 2016).

\subsection{Quantification of organo-nitrates in the flow tube}

The total N signal of Long-ToF-AMS was first determined using the approach proposed by Farmer et al. (2010). Briefly, the total mass concentration of N-containing compounds $\left[\boldsymbol{N}_{\boldsymbol{t o t}, \boldsymbol{O} \boldsymbol{N}}\right]$ was estimated with the following equation:

$$
\left[\mathrm{N}_{\text {tot }, \mathrm{ON}}\right]=\left[\mathrm{CHON}^{+}\right]+\left[\mathrm{NO}_{\mathrm{ON}}^{+}\right]+\left[\mathrm{NO}_{2, \mathrm{ON}}^{+}\right]
$$

where $\left[\mathrm{CHON}^{+}\right]$is the mass concentration of $\mathrm{C}_{\mathrm{x}} \mathrm{H}_{\mathrm{y}} \mathrm{O}_{\mathrm{z}} \mathrm{N}^{+}$fragments. The ratio of $\left[\mathrm{CHON}^{+}\right]$to $\left[\mathrm{N}_{\text {tot,ON }}\right]$ is RCHON:

$$
\mathrm{R}_{\mathrm{CHON}}=\left[\mathrm{CHON}^{+}\right] /\left[\mathrm{N}_{\text {tot,ON }}\right]
$$

$\mathrm{R}_{\mathrm{CHON}}$ is typically 0.05 for many ON compounds (Farmer et al., 2010). From the equations above, we derive the total concentration of $\mathrm{NO}^{+}$and $\mathrm{NO}_{2}{ }^{+}$from $\mathrm{ON}\left(\left[\mathrm{NO}_{\mathrm{ON}}^{+}\right]+\left[\mathrm{NO}_{2, \mathrm{ON}}^{+}\right]\right)$. The ON mass concentration was then calculated using the approached in the previous section. 


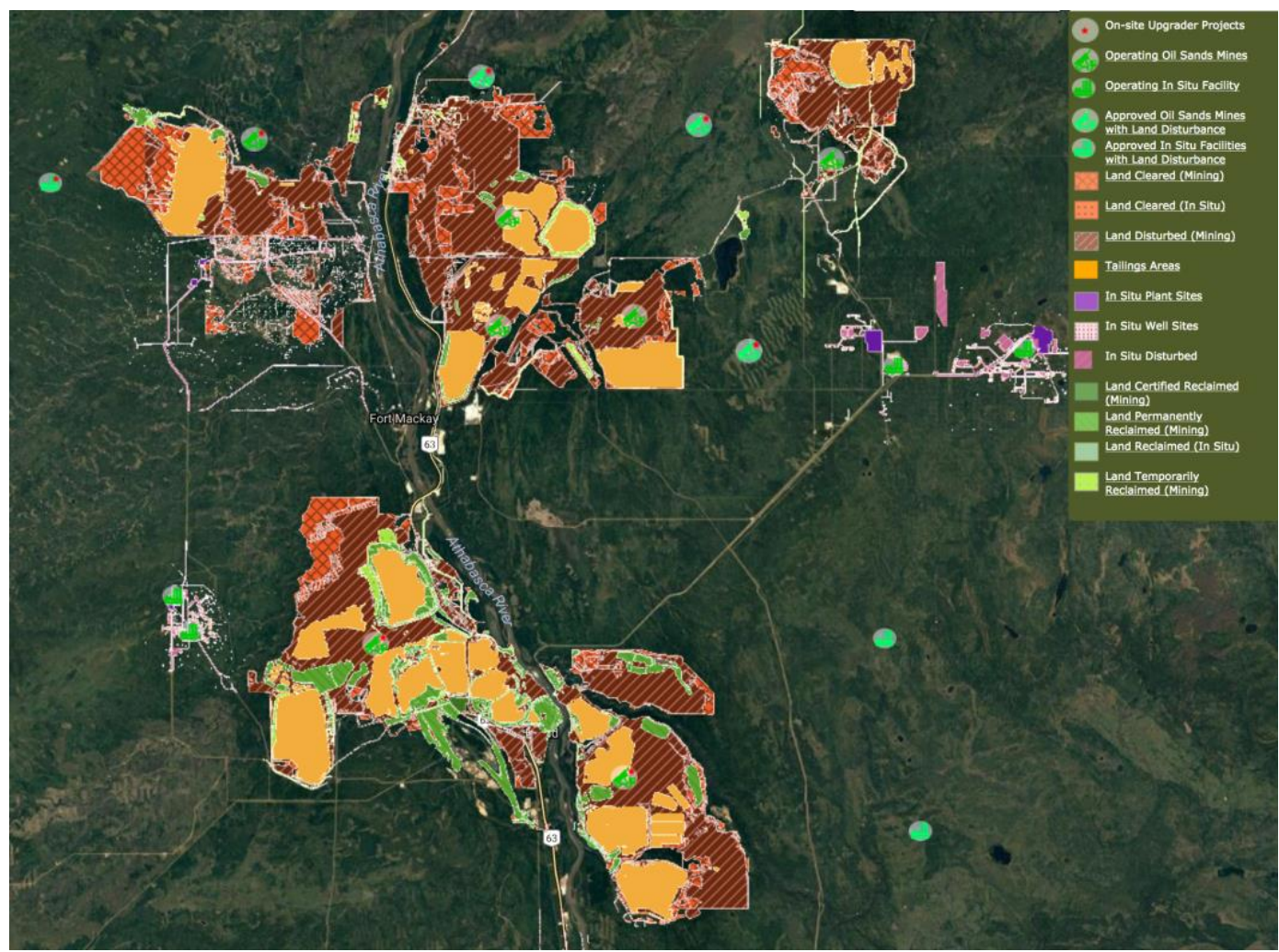

Figure S1: Map of oil sands facilities, downloaded from the Oil Sands Information Portal (Government of Alberta, oil sands information portal: http://osip.alberta.ca, access: FEB-2018) 

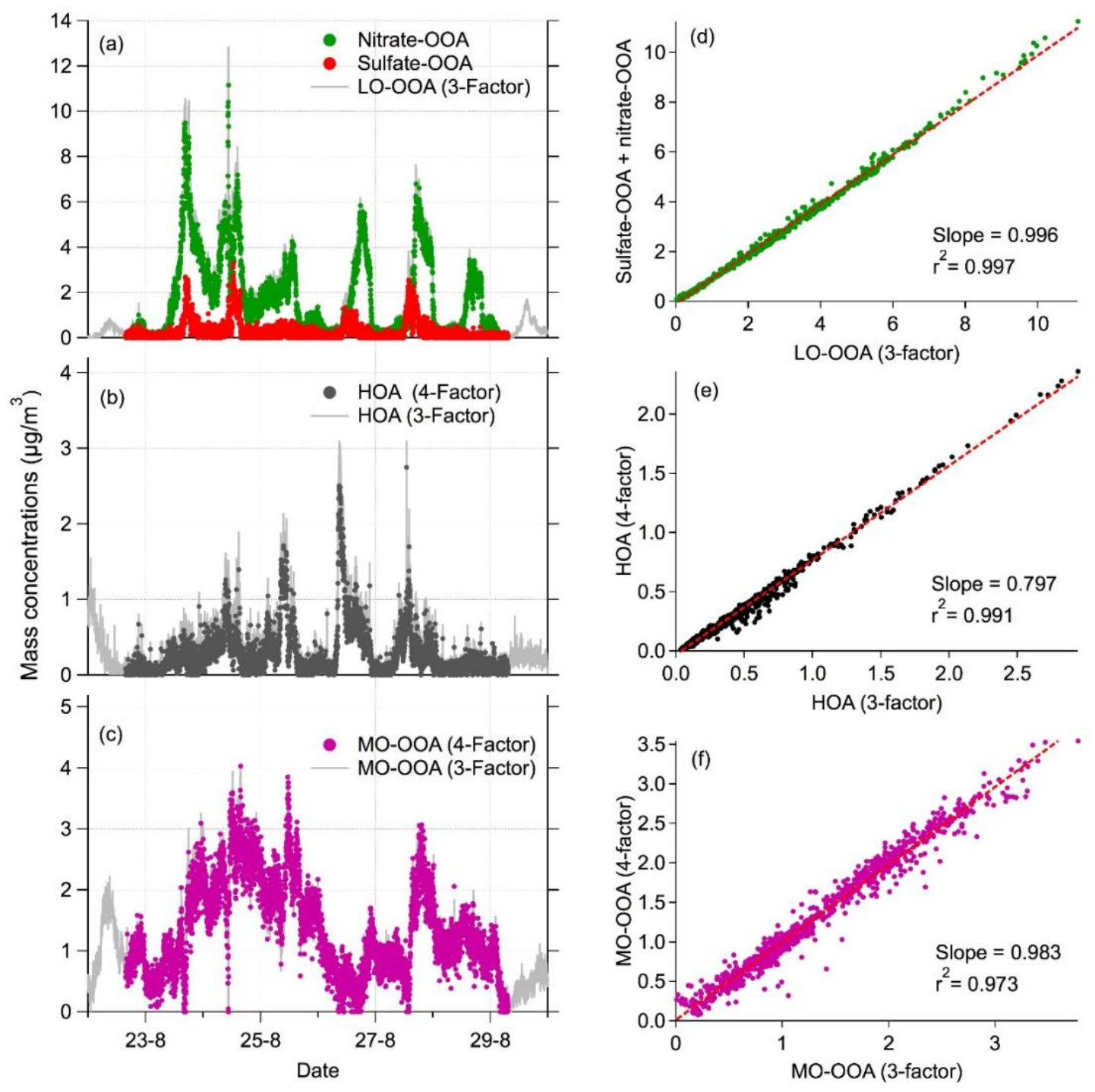

Figure S2: Time series of the PMF factors for the period August 22-29, 2013. Four distinct factors, namely HOA, MO-OOA, nitrate-OOA and sulfate-OOA, were identified. The LO-OOA factor (from 3-factor solution) split into nitrate-OOA and sulfate-OOA. 

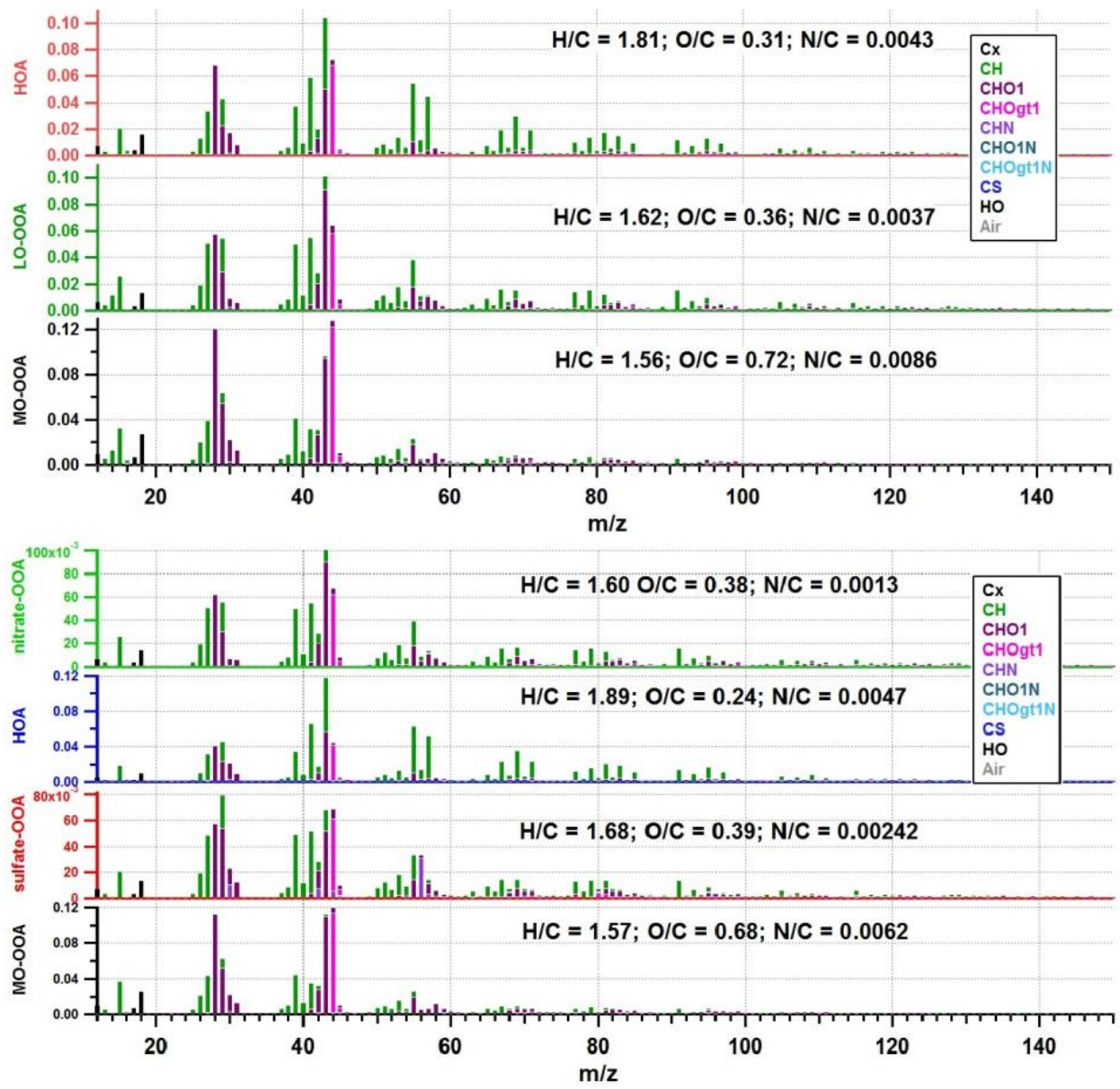

Figure S3: Mass spectra of PMF factors for the entire campaign period, 11 August - 10 September 2013 (Top three panels) and the period of August 22-29, 2013 (bottom four panels). 

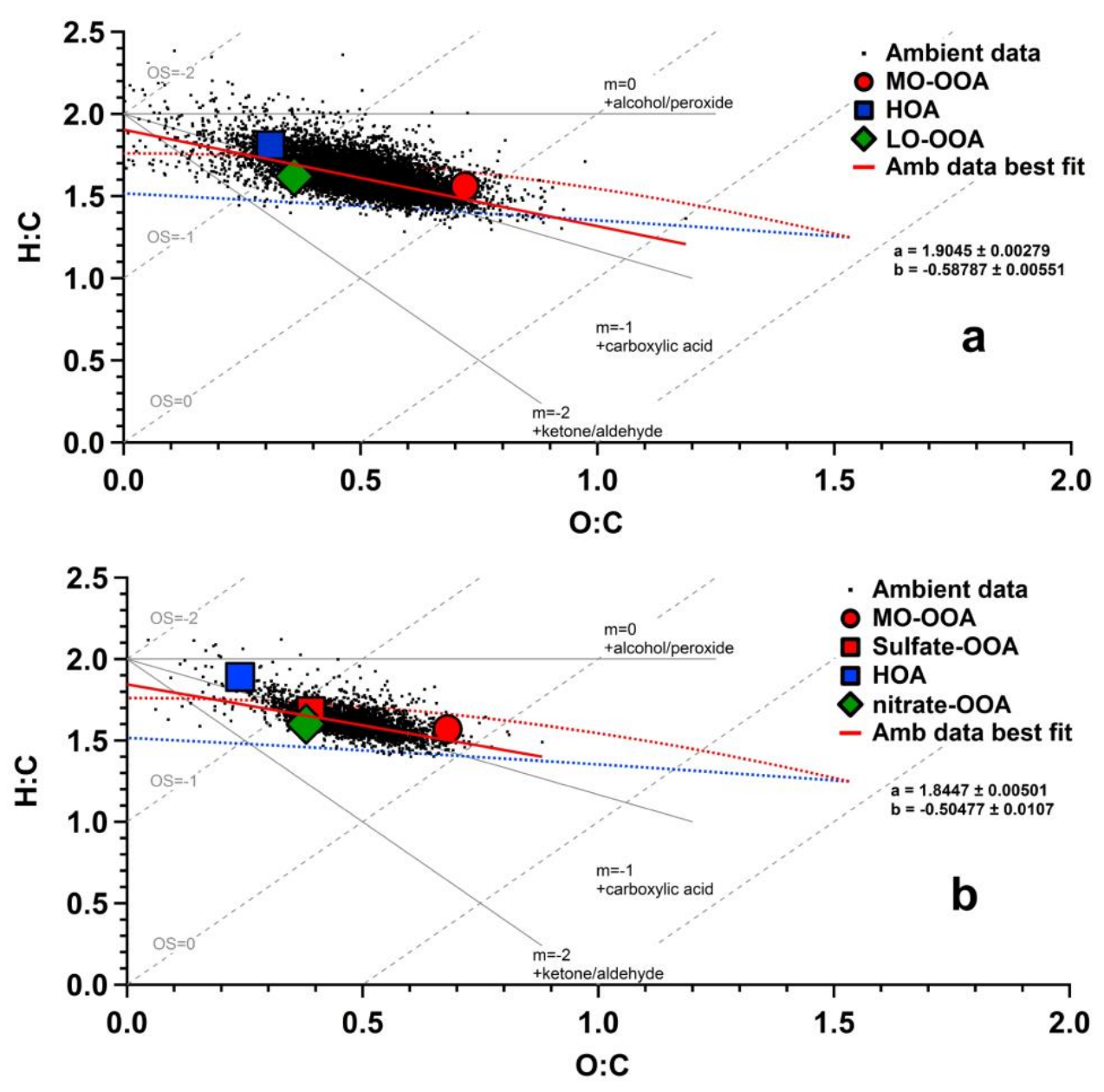

Figure S4: Van-Krevelen diagrams: Elemental ratios of ambient data and PMF factors were determined by the improved-ambient elemental ratio analysis method (Canagaratna et al., 2015) for a) the entire campaign period, and b) August 22-29, 2013. 

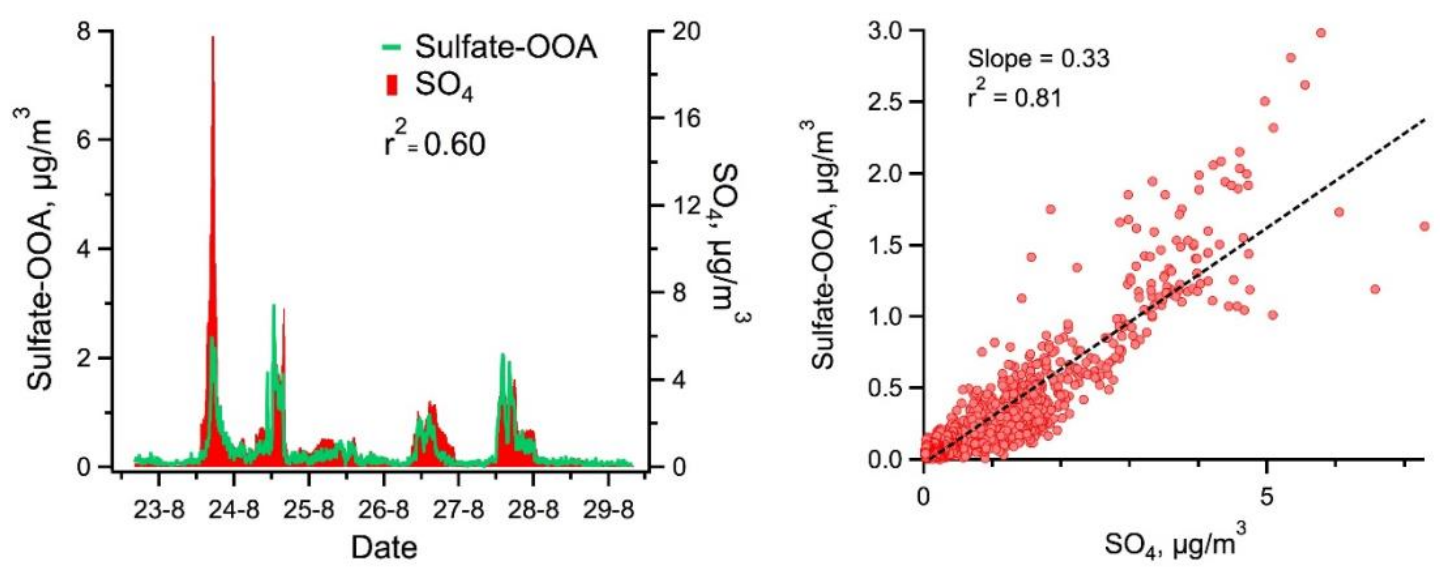

Figure S5: Left panel: Comparison of sulfate-OOA and sulfate mass loadings for the time period August 22-29, 2013. Right panel: Correlations between sulfate-OOA and sulfate mass loadings (excluding the strong sulfate plume observed on August 23). 


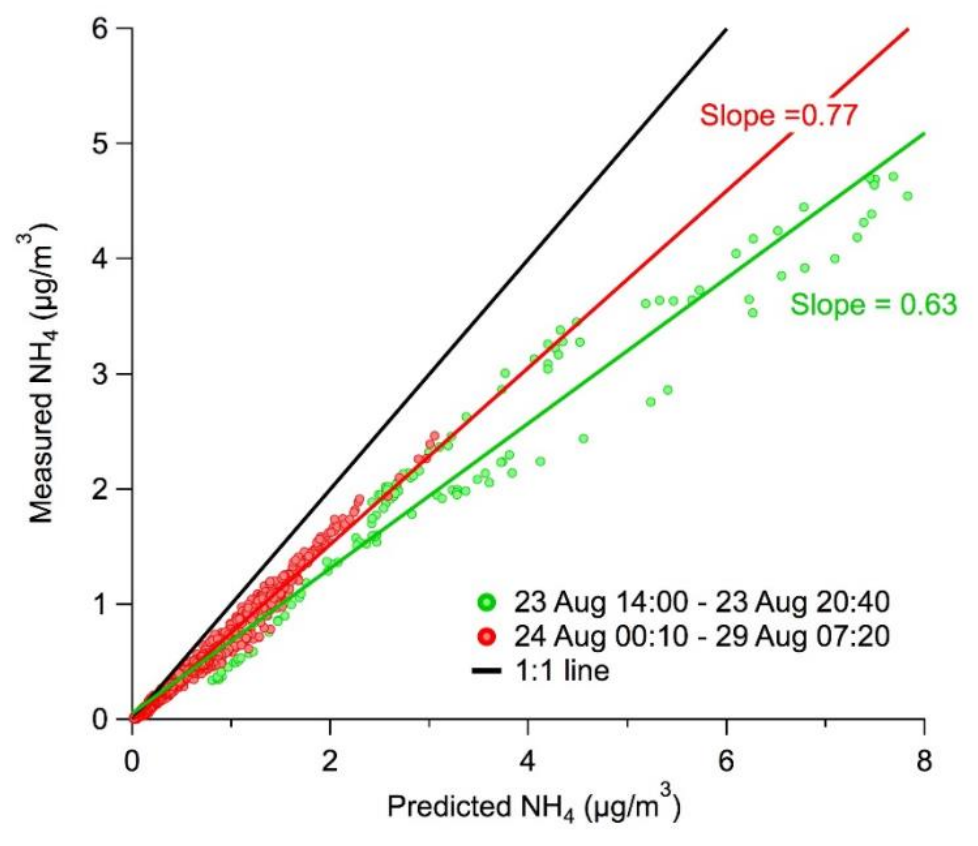

Figure S6: Plot of measured ammonium vs predicted ammonium to illustrate the different degree of neutralization of aerosol particles, i.e. the strongest sulfate plume in green circles (August 23, 14:00 20:40) and the remaining period in red circles (from August 24, 00:10 to August 29, 07:20). 


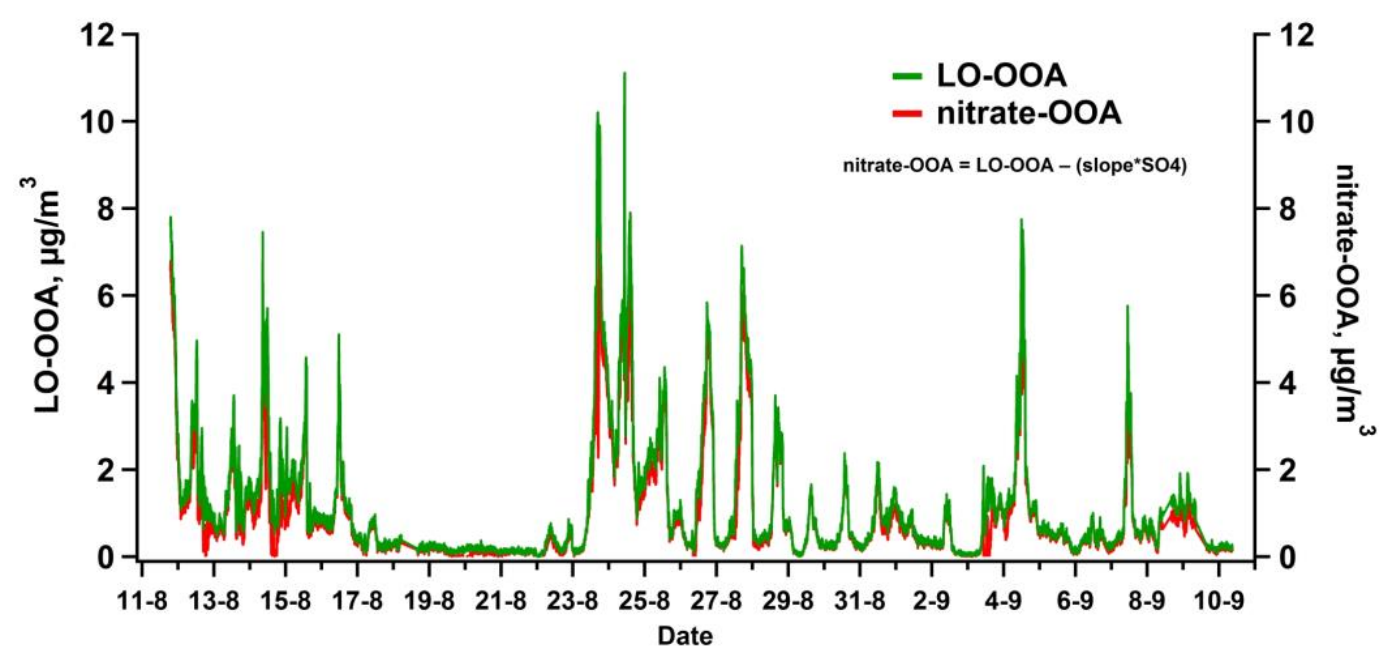

Figure S7: Time series of the LO-OOA factor and the estimated nitrate-OOA for the entire campaign period. The correlation coefficient $\left(\mathrm{r}^{2}\right)$ between the LO-OOA factor and nitrate-OOA is 0.95 . 


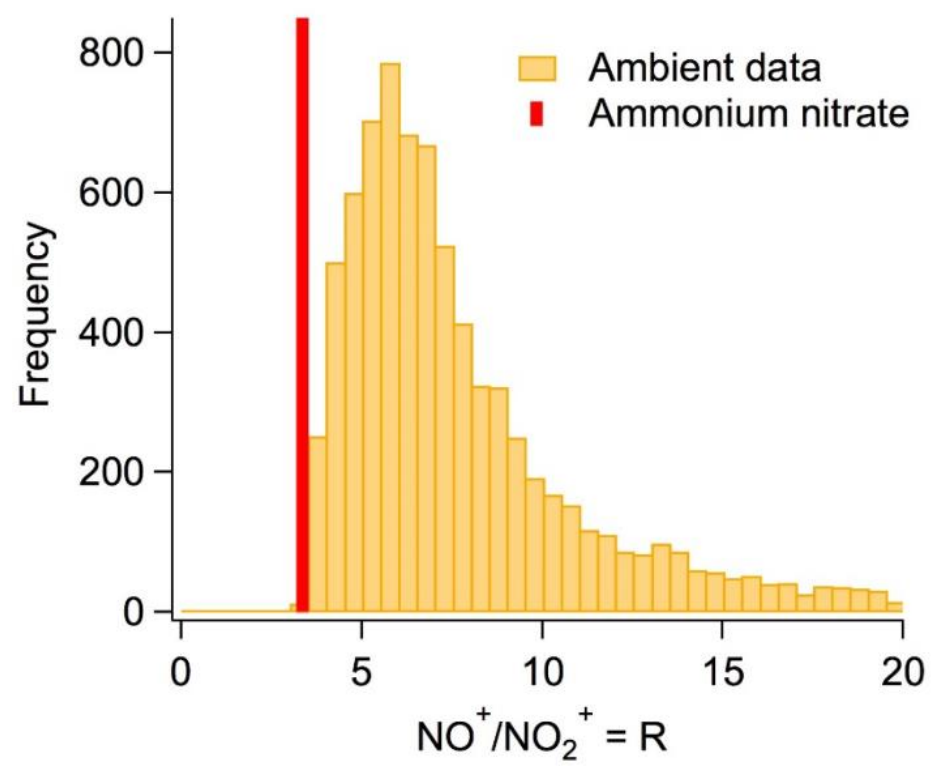

Figure S8: Histogram of $\mathrm{NO}^{+} / \mathrm{NO}_{2}{ }^{+}$ratio for ambient data from ground-based measurements. The ratio for pure ammonium nitrate is 3.36 . 


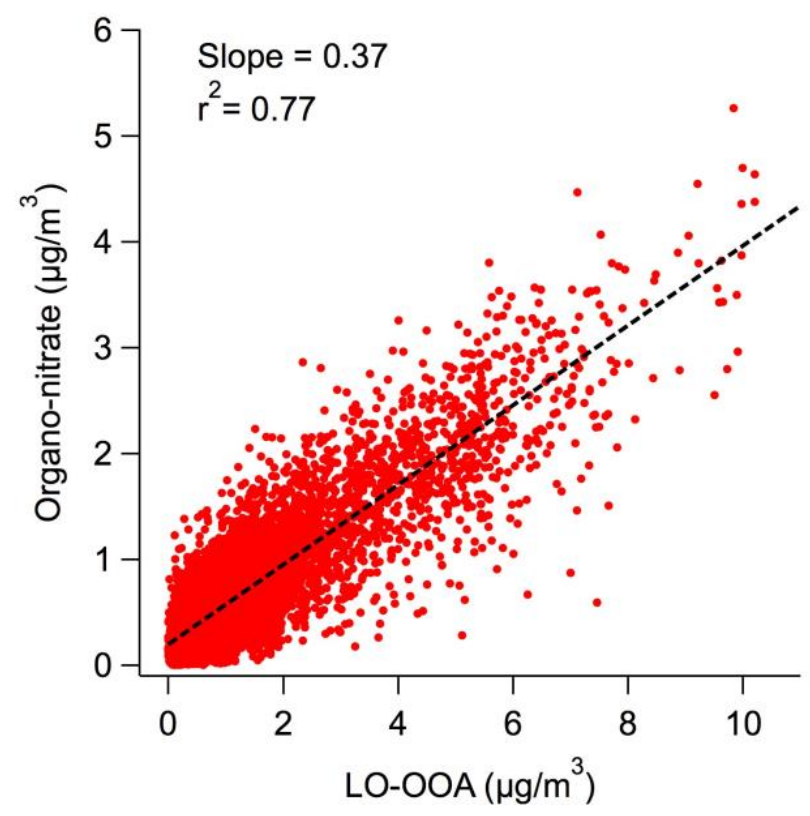

Figure S9: Contribution of organo-nitrate to the LO-OOA estimated by assuming $\mathrm{MW}_{\mathrm{ON}}=300 \mathrm{~g} / \mathrm{mol}$ and $R_{O N}=5$. Table S3 summarizes the results of calculation by varying MWON and RON. 

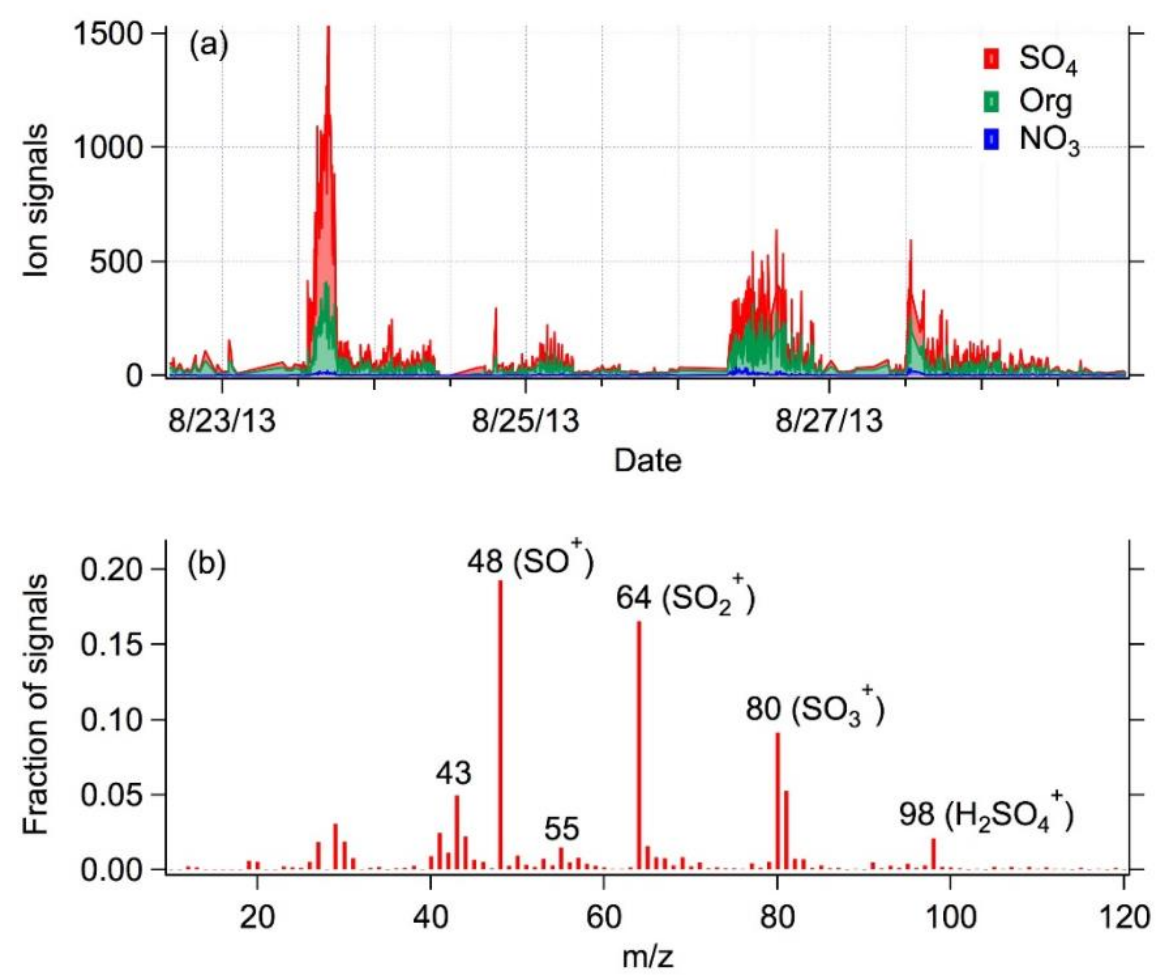

Figure S10: (a) Time series (ion signals) and (b) mass spectrum of the sulfate-rich particle type identified by clustering of single particle measurement. 


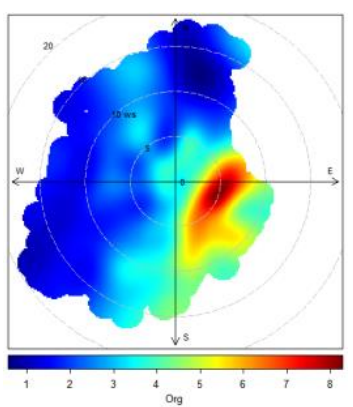

(a) Organic

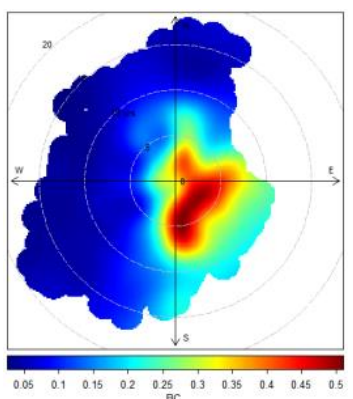

(e) $\mathrm{BC}$

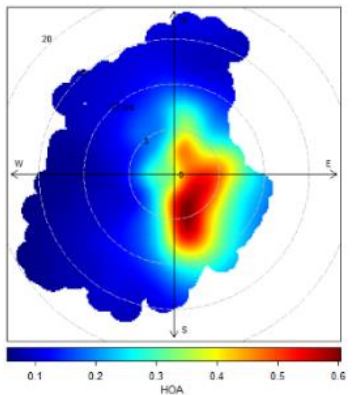

(i) $\mathrm{HOA}$

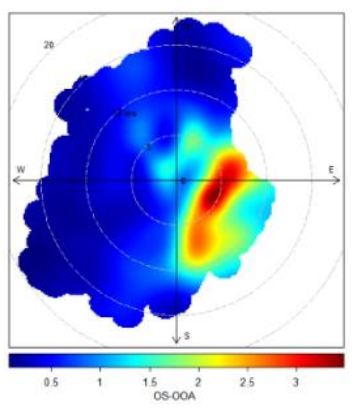

(m) Nitrate-OOA

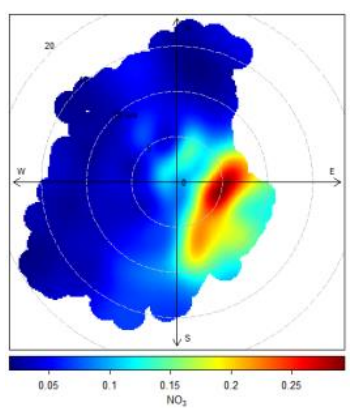

(b) $\mathrm{NO}_{3}$

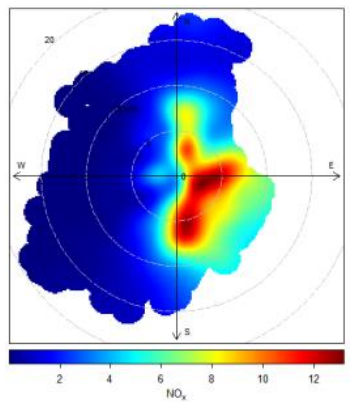

(f) $\mathrm{NO}_{\mathrm{x}}$

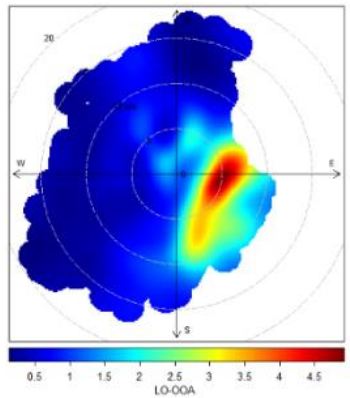

(j) LO-OOA

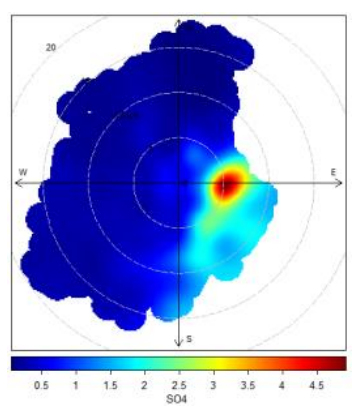

(c) $\mathrm{SO}_{4}$

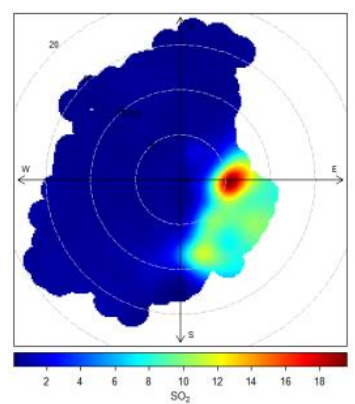

(g) $\mathrm{SO}_{2}$

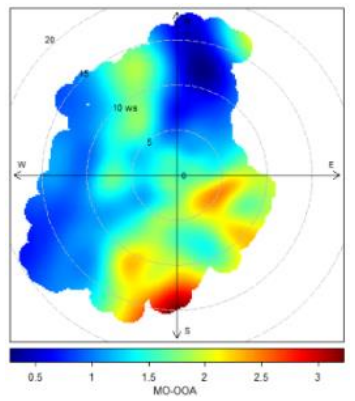

(k) MO-OOA

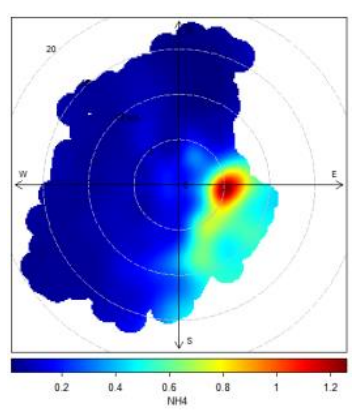

(d) $\mathrm{NH}_{4}$

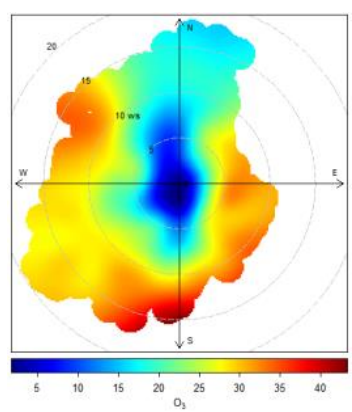

(h) $\mathrm{O}_{3}$

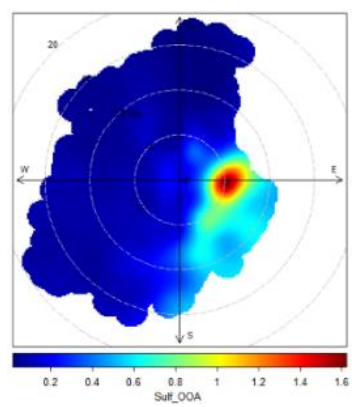

(1) Sulfate-OOA

Figure S11: Bivariate polar plots of aerosol and gas-phase species for the entire sampling period. 


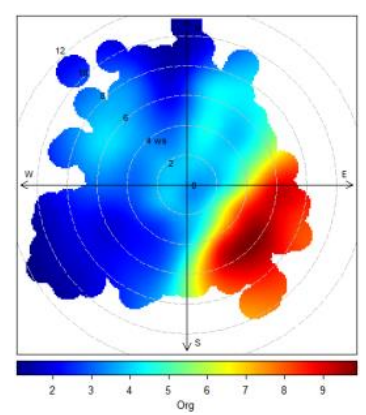

(a) Organic

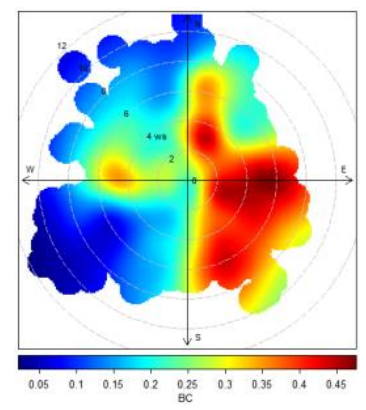

(e) BC

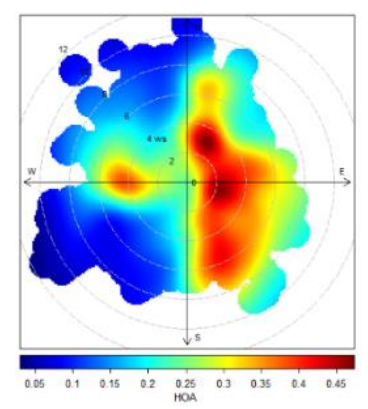

(i) $\mathrm{HOA}$

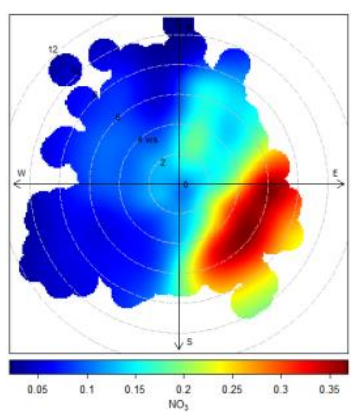

(b) $\mathrm{NO}_{3}$

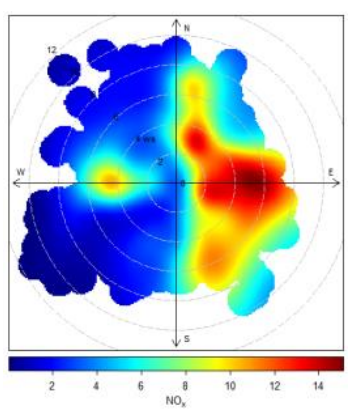

(f) $\mathrm{NO}_{\mathrm{x}}$

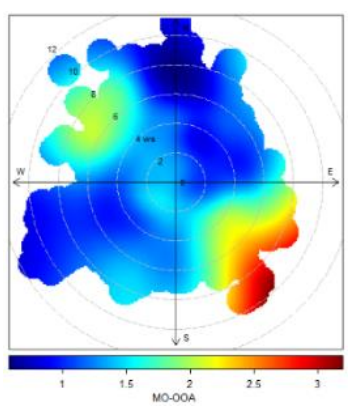

(j) MO-OOA

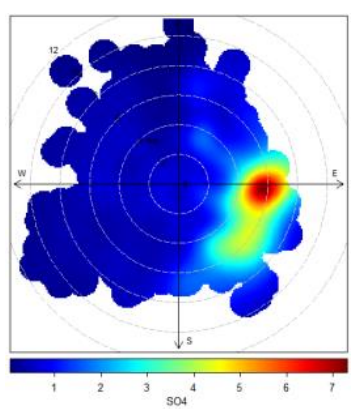

(c) $\mathrm{SO}_{4}$

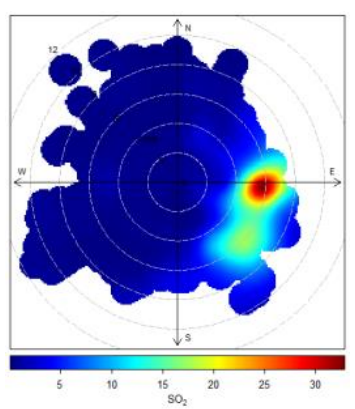

(g) $\mathrm{SO}_{2}$

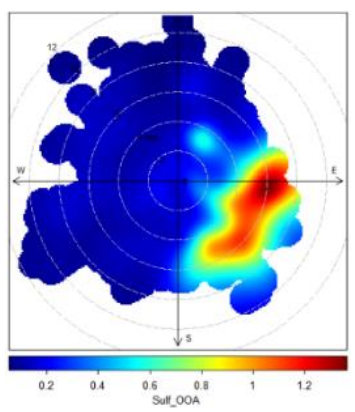

(k) Sulfate-OOA

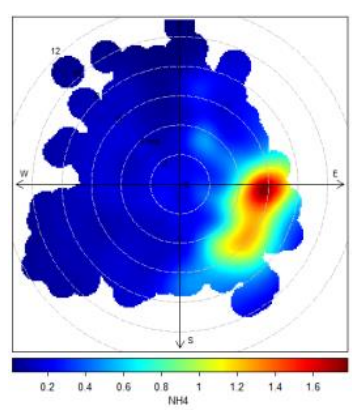

(d) $\mathrm{NH}_{4}$

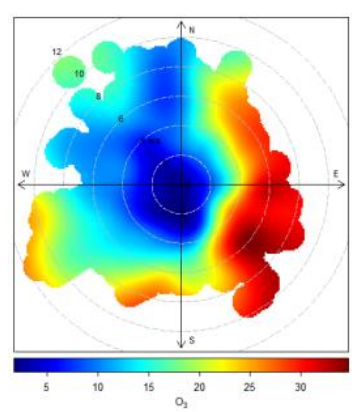

(h) $\mathrm{O}_{3}$

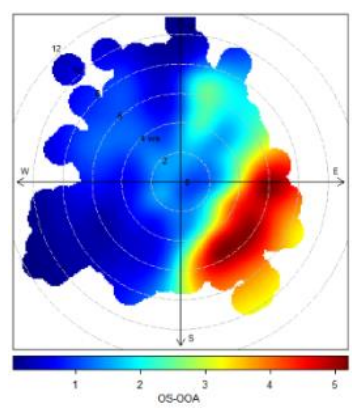

(1) Nitrate-OOA

Figure S12: Bivariate polar plots of aerosol and gas-phase species for August 22- 29, 2013. 


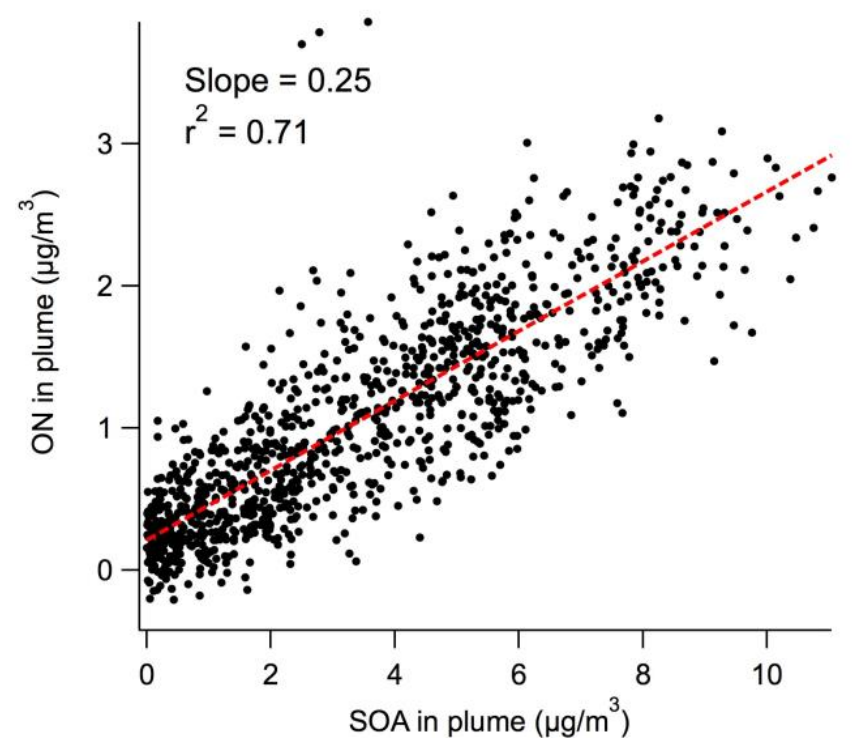

Figure S13: Correlation between $\mathrm{ON}$, with molecular weight $300 \mathrm{~g} / \mathrm{mol}$ and $\mathrm{R}=5$, and the fresh SOA component observed from the aircraft measurements. The upper limit contribution of the ON to the fresh SOA is approximately $34 \%$. Table S4 summarizes the results of calculation by varying MWON and RON. 
Table S1: Correlations of different aerosol and gas-phase species for the entire sampling period at the ground site

\begin{tabular}{|c|c|c|c|c|c|c|c|c|c|c|c|c|c|}
\hline Species & Org & $\mathrm{NO}_{3}$ & $\mathrm{SO}_{4}$ & $\mathbf{N H}_{4}$ & BC & $\mathrm{NO}_{\mathrm{x}}$ & $\mathrm{SO}_{2}$ & $\mathrm{O}_{3}$ & HOA & $\begin{array}{l}\text { LO- } \\
\text { OOA }\end{array}$ & $\begin{array}{l}\text { MO- } \\
\text { OOA }\end{array}$ & $\begin{array}{c}\text { Sulfate- } \\
\text { OOA }\end{array}$ & $\begin{array}{c}\text { Nitrate- } \\
\text { OOA }\end{array}$ \\
\hline Org & & 0.78 & 0.39 & 0.44 & 0.28 & 0.13 & 0.12 & 0.00 & 0.19 & 0.82 & 0.52 & 0.39 & 0.78 \\
\hline $\mathrm{NO}_{3}$ & & & 0.45 & 0.50 & 0.25 & 0.19 & 0.20 & 0.00 & 0.25 & 0.88 & 0.15 & 0.45 & 0.82 \\
\hline $\mathrm{SO}_{4}$ & & & & 0.97 & 0.07 & 0.09 & 0.75 & 0.05 & 0.08 & 0.46 & 0.07 & NA & 0.26 \\
\hline $\mathrm{NH}_{4}$ & & & & & 0.09 & 0.11 & 0.69 & 0.04 & 0.11 & 0.49 & 0.09 & 0.97 & 0.29 \\
\hline BC & & & & & & 0.72 & 0.00 & 0.10 & 0.70 & 0.17 & 0.07 & 0.07 & 0.17 \\
\hline $\mathrm{NO}_{\mathrm{x}}$ & & & & & & & 0.05 & 0.05 & 0.73 & 0.11 & 0.00 & 0.07 & 0.09 \\
\hline $\mathrm{SO}_{2}$ & & & & & & & & 0.07 & 0.02 & 0.22 & 0.00 & 0.75 & 0.09 \\
\hline $\mathrm{O}_{3}$ & & & & & & & & & 0.10 & 0.00 & 0.02 & 0.05 & 0.00 \\
\hline HOA & & & & & & & & & & 0.13 & 0.00 & 0.08 & 0.12 \\
\hline $\begin{array}{l}\text { LO- } \\
\text { OOA }\end{array}$ & & & & & & & & & & & 0.16 & 0.46 & 0.95 \\
\hline $\begin{array}{l}\text { MO- } \\
\text { OOA }\end{array}$ & & & & & & & & & & & & 0.07 & 0.15 \\
\hline $\begin{array}{l}\text { Sulfate- } \\
\text { OOA }\end{array}$ & & & & & & & & & & & & & 0.26 \\
\hline $\begin{array}{l}\text { Nitrate- } \\
\text { OOA }\end{array}$ & & & & & & & & & & & & & \\
\hline
\end{tabular}


Table S2: Correlations of different aerosol and gas-phase species for August 22- 29, 2013 at the ground site

\begin{tabular}{|c|c|c|c|c|c|c|c|c|c|c|c|c|c|}
\hline Species & Org & $\mathrm{NO}_{3}$ & $\mathrm{SO}_{4}$ & $\mathrm{NH}_{4}$ & BC & $\begin{array}{c}\text { NO } \\
\mathrm{x}\end{array}$ & $\mathrm{SO}_{2}$ & $\mathbf{O}_{3}$ & HOA & $\begin{array}{l}\text { LO- } \\
\text { OOA }\end{array}$ & $\begin{array}{l}\text { MO- } \\
\text { OOA }\end{array}$ & $\begin{array}{c}\text { Sulfate } \\
\text {-OOA }\end{array}$ & $\begin{array}{l}\text { Nitrate } \\
\text {-OOA }\end{array}$ \\
\hline Org & & 0.86 & 0.40 & 0.47 & 0.26 & 0.08 & 0.24 & 0.14 & 0.12 & NA & 0.37 & 0.45 & 0.91 \\
\hline $\mathrm{NO}_{3}$ & & & 0.43 & 0.50 & 0.39 & 0.18 & 0.27 & 0.13 & 0.26 & NA & 0.18 & 0.45 & 0.81 \\
\hline $\mathrm{SO}_{4}$ & & & & 0.97 & 0.14 & 0.13 & 0.88 & 0.20 & 0.06 & NA & 0.00 & 0.60 & 0.42 \\
\hline $\mathbf{N H}_{4}$ & & & & & 0.17 & 0.15 & 0.79 & 0.18 & 0.09 & NA & 0.02 & 0.65 & 0.46 \\
\hline BC & & & & & & 0.81 & 0.03 & 0.00 & 0.83 & NA & 0.00 & 0.19 & 0.20 \\
\hline NO $_{x}$ & & & & & & & 0.05 & 0.00 & 0.81 & NA & 0.03 & 0.18 & 0.05 \\
\hline $\mathrm{SO}_{2}$ & & & & & & & & 0.29 & 0.00 & $\mathrm{NA}$ & 0.00 & 0.47 & 0.27 \\
\hline $\mathbf{O}_{3}$ & & & & & & & & & 0.02 & NA & 0.00 & 0.13 & 0.20 \\
\hline HOA & & & & & & & & & & NA & 0.00 & 0.10 & 0.07 \\
\hline $\begin{array}{l}\text { LO- } \\
\text { OOA }\end{array}$ & & & & & & & & & & & NA & NA & NA \\
\hline $\begin{array}{l}\text { MO- } \\
\text { OOA }\end{array}$ & & & & & & & & & & & & 0.04 & 0.17 \\
\hline $\begin{array}{c}\text { Sulfate- } \\
\text { OOA }\end{array}$ & & & & & & & & & & & & & 0.36 \\
\hline $\begin{array}{c}\text { Nitrate- } \\
\text { OOA }\end{array}$ & & & & & & & & & & & & & \\
\hline
\end{tabular}


Table S3: Percentage contribution of organo-nitrate to the LO-OOA factor at the ground site based upon different values for Ron and molecular weight.

\begin{tabular}{|c|c|c|}
\hline RoN $\left(\mathbf{N O}^{+} / \mathrm{NO}_{2}{ }^{+}\right)$ & $\begin{array}{c}\text { Molecular weight } \\
(\mathbf{M W} \text { on, } \mathbf{g} / \mathbf{m o l})\end{array}$ & $\begin{array}{c}\text { \% contribution of ON to nitrate-OOA } \\
(\text { mean } \pm \text { 1 standard deviation })\end{array}$ \\
\hline 5 & 200 & $42( \pm 22 \%)$ \\
\hline 5 & 300 & $53 \%( \pm 22 \%)$ \\
\hline 10 & 200 & $24( \pm 17 \%)$ \\
\hline 10 & 300 & $33( \pm 20 \%)$ \\
\hline
\end{tabular}




\section{References}

Allan, J. D., Delia, A. E., Coe, H., Bower, K. N., Alfarra, M. R., Jimenez, J. L., Middlebrook, A. M., Drewnick, F., Onasch, T. B., and Canagaratna, M. R.: A generalised method for the extraction of chemically resolved mass spectra from Aerodyne aerosol mass spectrometer data, Journal of Aerosol Science, 35, 909-922, 2004.

Atkinson, R., and Arey, J.: Atmospheric Degradation of Volatile Organic Compounds, Chemical Reviews, 103, 4605-4638, 10.1021/cr0206420, 2003.

Canagaratna, M., Jayne, J., Jimenez, J., Allan, J., Alfarra, M., Zhang, Q., Onasch, T., Drewnick, F., Coe, H., and Middlebrook, A.: Chemical and microphysical characterization of ambient aerosols with the aerodyne aerosol mass spectrometer, Mass Spectrometry Reviews, 26, 185-222, 2007.

Canagaratna, M., Jimenez, J., Kroll, J., Chen, Q., Kessler, S., Massoli, P., Hildebrandt Ruiz, L., Fortner, E., Williams, L., and Wilson, K.: Elemental ratio measurements of organic compounds using aerosol mass spectrometry: characterization, improved calibration, and implications, Atmospheric Chemistry and Physics, 15, 253-272, 2015.

Carslaw, D. C., and Beevers, S. D.: Characterising and understanding emission sources using bivariate polar plots and k-means clustering, Environmental modelling \& software, 40, 325-329, 2013.

Cross, E., Onasch, T. B., Canagaratna, M., Jayne, J., Kimmel, J., Yu, X.-Y., Alexander, M., Worsnop, D. R., and Davidovits, P.: Single particle characterization using a light scattering module coupled to a timeof-flight aerosol mass spectrometer, Atmospheric Chemistry and Physics, 9, 7769-7793, 2009.

DeCarlo, P. F., Kimmel, J. R., Trimborn, A., Northway, M. J., Jayne, J. T., Aiken, A. C., Gonin, M., Fuhrer, K., Horvath, T., and Docherty, K. S.: Field-deployable, high-resolution, time-of-flight aerosol mass spectrometer, Analytical chemistry, 78, 8281-8289, 2006.

Englander, J. G., Bharadwaj, S., and Brandt, A. R.: Historical trends in greenhouse gas emissions of the Alberta oil sands (1970-2010), Environmental Research Letters, 8, 044036, 2013.

Farmer, D., Matsunaga, A., Docherty, K., Surratt, J., Seinfeld, J., Ziemann, P., and Jimenez, J.: Response of an aerosol mass spectrometer to organonitrates and organosulfates and implications for atmospheric chemistry, Proceedings of the National Academy of Sciences, 107, 6670-6675, 2010.

Freutel, F., Drewnick, F., Schneider, J., Klimach, T., and Borrmann, S.: Quantitative single-particle analysis with the Aerodyne aerosol mass spectrometer: development of a new classification algorithm and its application to field data, Atmospheric Measurement Techniques, 6, 3131, 2013.

Fuchs, H., Dubé, W. P., Lerner, B. M., Wagner, N. L., Williams, E. J., and Brown, S. S.: A sensitive and versatile detector for atmospheric NO2 and NOx based on blue diode laser cavity ring-down spectroscopy, Environmental science \& technology, 43, 7831-7836, 2009. 
Hofzumahaus, A., Rohrer, F., Lu, K., Bohn, B., Brauers, T., Chang, C.-C., Fuchs, H., Holland, F., Kita, K., Kondo, Y., Li, X., Lou, S., Shao, M., Zeng, L., Wahner, A., and Zhang, Y.: Amplified Trace Gas Removal in the Troposphere, Science, 324, 1702-1704, 10.1126/science.1164566, 2009.

Irei, S., Takami, A., Sadanaga, Y., Nozoe, S., Yonemura, S., Bandow, H., and Yokouchi, Y.: Photochemical age of air pollutants, ozone, and secondary organic aerosol in transboundary air observed on Fukue Island, Nagasaki, Japan, Atmospheric Chemistry and Physics, 16, 4555-4568, 2016.

Jimenez, J. L., Jayne, J. T., Shi, Q., Kolb, C. E., Worsnop, D. R., Yourshaw, I., Seinfeld, J. H., Flagan, R. C., Zhang, X. F., Smith, K. A., Morris, J. W., and Davidovits, P.: Ambient aerosol sampling using the Aerodyne Aerosol Mass Spectrometer, Journal of Geophysical Research-Atmospheres, 108, 10.1029/2001jd001213, 2003.

Lee, A. K. Y., Willis, M. D., Healy, R. M., Onasch, T. B., and Abbatt, J. P. D.: Mixing state of carbonaceous aerosol in an urban environment: single particle characterization using the soot particle aerosol mass spectrometer (SP-AMS), Atmospheric Chemistry and Physics, 15, 1823-1841, 10.5194/acp15-1823-2015, 2015.

Li, S.-M., Leithead, A., Moussa, S. G., Liggio, J., Moran, M. D., Wang, D., Hayden, K., Darlington, A., Gordon, M., and Staebler, R.: Differences between measured and reported volatile organic compound emissions from oil sands facilities in Alberta, Canada, Proceedings of the National Academy of Sciences, 114, E3756-E3765, 2017.

Liggio, J., Li, S.-M., Hayden, K., Taha, Y. M., Stroud, C., Darlington, A., Drollette, B. D., Gordon, M., Lee, P., and Liu, P.: Oil sands operations as a large source of secondary organic aerosols, Nature, 534, 9194, 2016.

Liu, D., Allan, J., Whitehead, J., Young, D., Flynn, M., Coe, H., McFiggans, G., Fleming, Z. L., and Bandy, B.: Ambient black carbon particle hygroscopic properties controlled by mixing state and composition, Atmospheric Chemistry and Physics, 13, 2015-2029, 10.5194/acp-13-2015-2013, 2013.

Middlebrook, A. M., Bahreini, R., Jimenez, J. L., and Canagaratna, M. R.: Evaluation of compositiondependent collection efficiencies for the aerodyne aerosol mass spectrometer using field data, Aerosol Science and Technology, 46, 258-271, 2012.

Onasch, T., Trimborn, A., Fortner, E., Jayne, J., Kok, G., Williams, L., Davidovits, P., and Worsnop, D.: Soot particle aerosol mass spectrometer: development, validation, and initial application, Aerosol Science and Technology, 46, 804-817, 2012.

Paul, D., and Osthoff, H. D.: Absolute measurements of total peroxy nitrate mixing ratios by thermal dissociation blue diode laser cavity ring-down spectroscopy, Analytical chemistry, 82, 6695-6703, 2010.

Stone, D., Whalley, L. K., and Heard, D. E.: Tropospheric OH and HO2 radicals: field measurements and model comparisons, Chem Soc Rev, 41, 6348-6404, 10.1039/C2CS35140D, 2012.

Strawbridge, K.: Developing a portable, autonomous aerosol backscatter lidar for network or remote operations, Atmospheric Measurement Techniques, 6, 801-816, 2013. 
Takegawa, N., Kondo, Y., Koike, M., Chen, G., Machida, T., Watai, T., Blake, D., Streets, D., Woo, J. H., and Carmichael, G.: Removal of NOx and NOy in Asian outflow plumes: Aircraft measurements over the western Pacific in January 2002, Journal of Geophysical Research: Atmospheres, 109, doi:10.1029/2004JD004866, 2004.

Tokarek, T. W., Odame-Ankrah, C. A., Huo, J. A., McLaren, R., Lee, A. K. Y., Adam, M. G., Willis, M. D., Abbatt, J. P. D., Mihele, C., Darlington, A., Mittermeier, R. L., Strawbridge, K., Hayden, K. L., Olfert, J. S., Schnitzler, E. G., Brownsey, D. K., Assad, F. V., Wentworth, G. R., Tevlin, A. G., Worthy, D. E. J., Li, S. M., Liggio, J., Brook, J. R., and Osthoff, H. D.: Principal component analysis of summertime ground site measurements in the Athabasca oil sands: Sources of IVOCs, Atmos. Chem. Phys. Discuss., 2018, 153, 10.5194/acp-2017-1026, 2018.

Ulbrich, I. M., Canagaratna, M. R., Zhang, Q., Worsnop, D. R., and Jimenez, J. L.: Interpretation of organic components from Positive Matrix Factorization of aerosol mass spectrometric data, Atmospheric Chemistry and Physics, 9, 2891-2918, 10.5194/acp-9-2891-2009, 2009.

Willis, M., Lee, A., Onasch, T., Fortner, E., Williams, L., Lambe, A., Worsnop, D., and Abbatt, J.: Collection efficiency of the soot-particle aerosol mass spectrometer (SP-AMS) for internally mixed particulate black carbon, Atmospheric Measurement Techniques, 7, 4507-4516, 2014.

Xu, L., Guo, H., Boyd, C. M., Klein, M., Bougiatioti, A., Cerully, K. M., Hite, J. R., Isaacman-VanWertz, G., Kreisberg, N. M., and Knote, C.: Effects of anthropogenic emissions on aerosol formation from isoprene and monoterpenes in the southeastern United States, Proceedings of the National Academy of Sciences, 112, 37-42, 2015.

Zhang, Q., Jimenez, J. L., Canagaratna, M. R., Ulbrich, I. M., Ng, N. L., Worsnop, D. R., and Sun, Y. L.: Understanding atmospheric organic aerosols via factor analysis of aerosol mass spectrometry: a review, Analytical and Bioanalytical Chemistry, 401, 3045-3067, 10.1007/s00216-011-5355-y, 2011. 